\title{
Diversity of neglected and underutilized crop species (NUCS) at Rancabuaya, South Garut West Java: potentially as human food
}

\begin{abstract}
Rancabuaya is one of the tourist destination located in Garut, West Java. The aim of this study was to collect information about diversity of neglected and underutilized plants and their potential as human foods, particularly in Caringin Village (Purbayani, Indralayang, Samudra Jaya and Cimahi village). The methods used in this research were direct observations (survey), semi-structured interviews, individual discussions, and key informant interviews. The survey was conducted on paddy fields, agroforestries, and homegardens. Neglected and underutilized crop species were identified by literature review from Arora (2014). Plants consisted of 133 species from 53 families. There were $97.0 \%$ of total plants in Rancabuaya known as food crops. It consisted of 99species from 42 families of food crops in Rancabuaya. More than $64 \%$ of total food crops were included to NUCS. More than $74.5 \%$ oftotal crop species in Rancabuaya categorized as vegetables and fruit plant (52 species as NUCS). There were 2 species categorized as cereals (NUCS were not found), 5 species as legumes (2 NUCS), 5 species as tubers (3 NUCS), 34 species as vegetables (28 NUCS), 39 species as fruit plants (28 NUCS), 12 species as herbs (6 NUCS) and 2 species categorized as others (1 NUCS). Review of the literature available revealed that many of neglected crops are rich in nutrient, has a potential for further food development, and potential to be promoted in market. Unfortunately, insufficiency of promotion from national policy and the lack of development of organized market could be the main reasons of their negligence.
\end{abstract}

Keywords: diversity, food crops, interview, neglected, survey, underutilized, Rancabuaya
Volume 2 Issue 4 - 2018

\author{
Teguh Husodo, Annisa, HerriY Hadikusumah, \\ Mohammad Nurzaman, Tia Setiawati, Joko \\ Kusmoro, Asep Z Mutaqin, Karyono,Annas \\ Dwitri Malik
}

Department of Biology, Padjadjaran University, Indonesia

Correspondence: Annas Dwitri Malik, Department of Biology, Faculty of Mathematics and Natural Sciences, Padjadjaran University, Jl. Raya Bandung-Sumedang, Jatinangor Sumedang, 45363 West Java, Indonesia, Tel +62 22-77964I2, Email annas.dm27@gmail.com

Received: March 30, 2018 | Published: July 12, 2018

\section{Introduction}

Across the world, many species of plants are cultivated to provide human needs, such as food, clothing, shelter, and health care. Nowadays, majority of farmers prefer to cultivate plants which become our major commodity. For example, in Indonesia, rice paddy is still a major source of carbohydrates. Human needs of these staple crops are growing rapidly because of growing world population, increasing incomes and urbanization. In that case, relying on such a narrow food base makes our food supply extremely vulnerable. Basing our diet on a very small number of major crops has dire implication for both food security and nutrition. ${ }^{1}$ The lack of diversity within of gene pools of these few crop species will leave our agricultural systems vulnerable to disease and abiotic stress.

Generally, farmers lived in marginal area cultivated not only staple crops but also various types of plants. Many of those crop species are potentially grown as human foods. However, they are not well-known by majority of users' group. We can define those plants as neglected and underutilized crop species (NUCS). Padulosi $\&$ Hoeschle-Zeledon ${ }^{2}$ give a definition of NUCS as non-commodity crops, which are part of a larger biodiversity portfolio, once more popular and today are not entirely neglected by users' groups for a variety of agronomic, genetic, economic, social and cultural factors. For instance; researchers, breeders, and policy makers.

Rancabuaya is one of the tourist destination located at Caringin district, Garut, West Java. This area is very interesting because it has natural beauty which comes from combination of sea and hills. Caringin district has several villages namely: Purbayani, Indrajaya, Cimahi, Sukarame and Samudra Jaya. Based on land use, $48 \%$ of the area is covered by the paddy fields and agroforestry. ${ }^{3}$ The livelihood of community in Caringin are mostly farmers and traders. This region has used agroforestry system for its land management. This system combines crops and trees to be planted together. However, there has been no information regarding plants diversity, particularly the one that is neglected and underutilized by user's group and can be used as human foods.

Plants which grow in Rancabuaya area are mostly cultivated plants. They are grown in some of the existing land use. These plants have several functions i.e. as a source of food, medicine, spiceand use at cultural functions and as ornamental plants. Beside as source of food, cultivated plants in Rancabuaya could have an economic value that can help the villagers to receive an additional income. That is why it is necessary to conduct a study that can give valuable information of what plants are grown and how they are used by the people who live in Rancabuaya. The aim of this study was to collect information about diversity of neglected and underutilized plants and theirpotential as human food in Rancabuaya, Caringin District. This information will be used as a basis for research of management and development of agroforestry in this area.

\section{Materials and methods}

\section{Materials}

\section{Study area}

The area of this study at Rancabuaya, Caringin District, Garut (Figure 1). Caringin District is one of the district in Indonesia that most of the population livelihood as a farmer. Land biophysics in Caringin District has characteristics of small land cover condition, slope of 
$>15 \%$, erosion level between mild to severe, low land productivity, underutilized land management, rocky soil, shallow depth soil, poor drainage, low water holding power, rainfall and limited water availability. Climatic conditions are dry climates with wet season for 3-4 months and 6-9 months of dry season.

\section{Methods}

Four villages (Purbayani, Indralayang, Samudra Jaya and Cimahi village) were selected to carry out the field investigations. The information of plant species was collected using direct observation (survey), semi-structured interviews, individual discussions and key informant interviews. The survey was conducted on paddy field, agroforestry area, and homegarden. Plant objects for this research wereherbaceous plants, shrubs and trees. Food crops categorized into several categories. The categories were fruit plants, tubers, cereals, vegetables, and herbs/spice. A group of literature reviews synthesized by Arora ${ }^{4}$ in a scope of "Diversity in Underutilized Plants in AsiaPasific" was used to identify which crop species that have been included into NUCS.

\section{Results and discussion}

\section{Diversity of plants}

Plant diversity in Rancabuaya was founded in paddy field, agroforestry and homegarden. Plant consists of 133 species from 53 families. The most common family was Fabaceae around $11.18 \%$, followed by Solanaceae (8.20\%) and Poaceae (6.72\%). Fabaceae consists of 15 species and Solanaceae consists of 11 species. Solanaceae and Fabaceae have the largest number of species. Family contains of estimated around 18,000 species in 630 genera. Many species of this family are used as a crop because they have a high economic value. Percentage of plants diversity based on family in Rancabuaya is presented in Table 1.

Table I Percentageof Plant Diversity based on Plant Familiesin Rancabuaya, Garut

\begin{tabular}{lll}
\hline No. & Family & $\%$ \\
\hline 1 & Fabaceae & 11,18 \\
2 & Solanaceae & 8,20 \\
3 & Poaceae & 6,72 \\
4 & Musaceae & 4,48 \\
5 & Zingiberaceae & 4,48 \\
6 & Anacardiaceae & 3,73 \\
7 & Moraceae & 3,73 \\
8 & Brassicaceae & 2,98 \\
9 & Cucurbitaceae & 2,98 \\
10 & Meliaceae & 2,98 \\
11 & Rubiaceae & 2,98 \\
12 & Arecaceae & 2,23 \\
13 & Euphorbiaceae & 2,23 \\
14 & Lamiaceae & 2,23 \\
15 & Myrtaceae & 2,23 \\
16 & Rutaceae & 2,23 \\
17 & Amaryllidaceae & 1,49 \\
\hline & &
\end{tabular}

Citation: Husodo T, Annisa, Hadikusumah HY, et al. Diversity of neglected and underutilized crop species (NUCS) at Rancabuaya, South Garut West Java: potentially as human food. Biodiversity Int J. 20I8;2(4):322-329. DOI: I0.15406/bij.2018.02.0008I

\begin{tabular}{|c|c|c|}
\hline \multicolumn{3}{|c|}{ able Continued } \\
\hline No. & Family & $\%$ \\
\hline 18 & Apiaceae & $\mathrm{I}, 49$ \\
\hline 19 & Convolvulaveae & $\mathrm{I}, 49$ \\
\hline 20 & Leguminosae & 1,49 \\
\hline 21 & Malvaceae & $\mathrm{I}, 49$ \\
\hline 22 & Passifloraceae & $\mathrm{I}, 49$ \\
\hline 23 & Phyllanthaceae & $\mathrm{I}, 49$ \\
\hline 24 & Piperaceae & 1,49 \\
\hline 25 & Sapindaceae & 1,49 \\
\hline 26 & Acacieae & 0,75 \\
\hline 27 & Achariaceae & 0,75 \\
\hline 28 & Alismataceae & 0,75 \\
\hline 29 & Amaranthaceae & 0,75 \\
\hline 30 & Araceae & 0,75 \\
\hline 31 & Asparagaceae & 0,75 \\
\hline 32 & Bromeliaceae & 0,75 \\
\hline 33 & Cannabaceae & 0,75 \\
\hline 34 & Cannaceae & 0,75 \\
\hline 35 & Caricaceae & 0,75 \\
\hline 36 & Clusiaceae & 0,75 \\
\hline 37 & Combretaceae & 0,75 \\
\hline 38 & Compositae & 0,75 \\
\hline 39 & Crassulaceae & 0,75 \\
\hline 40 & Dioscoreaceae & 0,75 \\
\hline $4 I$ & Gnetaceae & 0,75 \\
\hline 42 & Graminaceae & 0,75 \\
\hline 43 & Lauraceae & 0,75 \\
\hline 44 & Menispermaceae & 0,75 \\
\hline 45 & Moringaceae & 0,75 \\
\hline 46 & Oxalidaceae & 0,75 \\
\hline 47 & Pandanaceae & 0,75 \\
\hline 48 & Pedaliaceae & 0,75 \\
\hline 49 & Pinaceae & 0,75 \\
\hline 50 & Rhamnaceae & 0,75 \\
\hline 51 & Sapindaceae & 0,75 \\
\hline 52 & Sterculiaceae & 0,75 \\
\hline 53 & Thymelaeceae & 0,75 \\
\hline
\end{tabular}

\section{Diversity of food crops and NUCS food crops}

Rancabuaya has a high diversity of food crops. There were 99 species from 42 families of food crops in Rancabuaya. Among of them, there were 63 species included to NUCS food crops according to Arora. ${ }^{4}$ It means, there were more than $64 \%$ food crops categorized as NUCS. The food crops were dominant plants grown by farmers in Rancabuaya ( $97,0 \%$ from total species of plant). The percentage of food crops diversity based on plant family in Rancabuaya is presented in Table 2. Family Solanaceae and Fabaceae are the most family found as food crops. Solanaceae and fabaceae have been found about $11 \%$ and $10 \%$ from total families of food crop in Rancabuaya. Fabaceae 
known as high economic value of food crops in the world. Fabaceae are herbs, shrubs, trees, lianas or vines usually bearing alternate, pinnately compound, pulvinate, stipulate leaves. N-fixing bacteria are common in two subfamilies: Mimosoideae and Papilionoideae. Members of the subfamily Papilionoideae are significant non-animal protein sources. They include some beans. Solanaceae family was also found in this district. Different varieties of peppers and tomato were also found at villagers' homegarden. Mostly these crops were used for private consumption. Based on the results, list of food crops and those were included in NUCS food crops at Rancabuaya can be seen at Table 3 .

Table 2 Percentage of Food Crop Diversity based on Plant Familyin Rancabuaya, Caringin District, Garut

\begin{tabular}{|c|c|c|}
\hline No. & Family & $\%$ \\
\hline 1 & Fabaceae & 10 \\
\hline 2 & Solanaceae & II \\
\hline 3 & Poaceae & 4 \\
\hline 4 & Musaceae & 6 \\
\hline 5 & Zingiberaceae & 6 \\
\hline 6 & Anacardiaceae & 5 \\
\hline 7 & Moraceae & 3 \\
\hline 8 & Brassicaceae & 4 \\
\hline 9 & Cucurbitaceae & 4 \\
\hline 10 & Rubiaceae & 3 \\
\hline II & Arecaceae & 3 \\
\hline 12 & Euphorbiaceae & 2 \\
\hline 13 & Lamiaceae & I \\
\hline 14 & Myrtaceae & 2 \\
\hline 15 & Rutaceae & 3 \\
\hline 16 & Amaryllidaceae & 2 \\
\hline 17 & Apiaceae & 2 \\
\hline 18 & Convolvulaveae & 2 \\
\hline 19 & Leguminosae & I \\
\hline 20 & Malvaceae & 1 \\
\hline 21 & Passifloraceae & 2 \\
\hline 22 & Phyllanthaceae & 2 \\
\hline 23 & Piperaceae & 2 \\
\hline 24 & Sapindaceae & 2 \\
\hline 25 & Achariaceae & I \\
\hline 26 & Alismataceae & I \\
\hline 27 & Amaranthaceae & I \\
\hline 28 & Araceae & I \\
\hline 29 & Asparagaceae & 1 \\
\hline 30 & Bromeliaceae & 1 \\
\hline 31 & Cannaceae & 1 \\
\hline 32 & Caricaceae & 1 \\
\hline 33 & Clusiaceae & I \\
\hline 34 & Dioscoreaceae & I \\
\hline 35 & Gnetaceae & I \\
\hline
\end{tabular}

\begin{tabular}{lll}
\multicolumn{2}{l}{ Table Continued } \\
\hline No. & Family & $\%$ \\
\hline 36 & Graminaceae & $\mathrm{I}$ \\
37 & Lauraceae & $\mathrm{I}$ \\
38 & Oxalidaceae & $\mathrm{I}$ \\
39 & Pandanaceae & $\mathrm{I}$ \\
40 & Pedaliaceae & $\mathrm{I}$ \\
$4 \mathrm{I}$ & Sapindaceae & $\mathrm{I}$ \\
\hline
\end{tabular}

Based on the result on Table 3, Rancabuaya has many species of fruits and vegetables that can be used by the people. The list above includes NUCS food crops that are relatively widely grown, native species locally grown and less known. Many of these plants come as trees which made the agroforestry management in this village. Usually, most of farmers cultivated woody plants alongside herbaceous, also included annual plants on their own farms. They are practicing a rotation system in cultivating plants. The combination of crop species within the farm will change gradually as the woody plants grow bigger. In the beginning of rotation, the land was dominated with annual plants which were cultivated alongside sapling of woody plants. In the next year, annual plants were harvested and woody plants grown bigger, also covered the ground with their canopy. In this phase, woody plants dominated the land. The more canopy covered the ground, the less variation of herbaceous plants can be cultivated on the farm. As the woody plants became adult, whether the woody plants are harvested or left depends on the farmers' decision. This traditional agroforestry system are practiced mostly in West Java. ${ }^{5-7}$ In Rancabuaya, annual plants cultivated in the first phase of rotation are staple crops such as Rice, Corn, and Beans. In the latter phase of rotation, Albizia moluccana usually intercropped with various types of Zingiber, such as Cardamom, Ginger, and Galangal.

According to the result of observation, food crops can be categorized as fruit plant, tubers, cereal, legumes, vegetables, herbs/ spice and other. Figure 2 shows that vegetables and fruit plant are the most food crops widely planted in Rancabuaya. More than 74\% (73 of 99) crop species in Rancabuaya are categorized as vegetables and fruit plant. Among total food crops, there were $64 \%$ crop species included to NUCS. Production of fruit and vegetables in Rancabuaya is a significant entity within the overall agricultural industry, making an important economic contribution in terms of supplying the domestic market. Vegetables and fruit plants planted by people in Rancabuaya not only in agroforestry area but also in yard to supplement their diets. There were 2 species categorized as cereal (NUCS were not found), 5 species as legumes (2 NUCS), 5 species as tuber (3 NUCS), 34 species as vegetables (24 NUCS), 39 species as fruit plant (28 NUCS), 12 species as herb/spice(6 NUCS) and 2 species categorized as other (1 NUCS). Part of plant which can be used as food are fruit, pod, leaves, tuber, rhizome and seed. Data of plant species as food crops shown in Table 3.

\section{Reasons of negligence of crop species}

Arora ${ }^{4}$ highlighted that underutilized plants listed in Asian-Pacific region are relatively widely grown and other native species locally grown, less known, or endemic to the area. Also, several species are confined to yards/homegardens. The lack of promotion of food crop diversity's from national policy could be the main reason of negligence of crop species in Rancabuaya. The government has been promoted the diversification of food crops production. Hitertho, the national research fund only focused on development of major crops, such as rice, corn, soybean, cassava and peanut according to Ministry of Agriculture of Indonesia. ${ }^{8}$ 
Table 3 Diversity of food crops and NUCS food crops at Rancabuaya, Caringin District, Garut

\begin{tabular}{|c|c|c|c|c|}
\hline Food crop categories & Local name & Species & NUCS & Part of plant used \\
\hline \multirow{4}{*}{ Cereal } & Jagung & Zea mays & & Seed \\
\hline & Padihuma & Oryza sativa & & Seed \\
\hline & Kacanghijau & Vignaradiata(L.) R.Wilczek & $\sqrt{ }$ & Seed \\
\hline & Kacangkedelai & Glycine soja Siebold\&Zucc. & & Seed \\
\hline \multirow[t]{5}{*}{ Legume } & Kacangpanjang & Vignasinensis & & Pod \\
\hline & Kacangroay & Phaseolus lunatus L. & $\sqrt{ }$ & Pod \\
\hline & Kacangtanah & Arachis hypogaea L. & & Seed \\
\hline & Taleus/talas & Colocasia esculenta (L) Schott & $\sqrt{ }$ & Tuber \\
\hline & Ganyol/ganyong & Canna discolor Lindl. & $\sqrt{ }$ & Tuber \\
\hline \multirow[t]{20}{*}{ Tubers } & Huibodas/ubiputih & Ipomoea batatas L. & & Tuber \\
\hline & Gadung & Dioscorea hispida Dennst. & $\sqrt{ }$ & Tuber \\
\hline & Singkong/ Sampeu & Manihot utilisima & & Tuber \\
\hline & Picung & Pangium edule Reinw & & Seed \\
\hline & Genjer & Limnocharis flava (L.) Buchenau & & Leave, flower \\
\hline & Bayam & Amaranthus hybridus L. & $\sqrt{ }$ & Leave \\
\hline & Bawangdaun & Allium fistullosum & $\sqrt{ }$ & Leave \\
\hline & Bawangmerah & Allium cepa $\mathrm{L}$. & & Tuber/bulb \\
\hline & Antanan & Centella asiatica (L.) Urb. & $\sqrt{ }$ & Leave \\
\hline & Seledri & Apium graveolens L. & & Leave \\
\hline & Kol & Brassica oleracea $\mathrm{L}$. & $\sqrt{ }$ & Leave and flower \\
\hline & Pecai & Brassica chinensis & $\sqrt{ }$ & Leave \\
\hline & Pekcay/pakcoy & Brassica sp. & $\sqrt{ }$ & Leave \\
\hline & Sosin & Brassica sp. & $\sqrt{ }$ & Leave \\
\hline & Kangkungdarat & Ipomoea reptans & $\sqrt{ }$ & Leave \\
\hline & Mentimun/ Bonteng & Cucumis sativus L. & $\sqrt{ }$ & Fruit \\
\hline & Paria/pare & Momordica charantia L. & $\sqrt{ }$ & Fruit \\
\hline & Buncis & Phaseolus vulgaris & $\sqrt{ }$ & Pod \\
\hline & Jengkol & Archidendron pauciflorum & $\sqrt{ }$ & Fruit \\
\hline & Petai/peuteuy & Parkia speciosa & $\sqrt{ }$ & Seed \\
\hline \multirow{17}{*}{ Vegetables } & Selong & Leuchaena leucocephala & $\sqrt{ }$ & Pod \\
\hline & Melinjo/tangkil & Gnetum gnemon & $\sqrt{ }$ & Fruit, flower, leave \\
\hline & Kemangi & Ocimum $x$ citriodorum Vis. & & Leave \\
\hline & Katuk & Sauropus androgynus (L.) Merr. & $\sqrt{ }$ & Leave \\
\hline & Turubuk & Saccharum spontaneum var. Edulis & $\sqrt{ }$ & Flower \\
\hline & Cabeinul & Capsicum sp. & & Fruit \\
\hline & Cabejapra & Capsicum sp. & & Fruit \\
\hline & Cabekeriting & Capsicum annuum L. & & Fruit \\
\hline & Caberawit & Capsicum frutescens $\mathrm{L}$. & & Fruit \\
\hline & Cabetanjung & Capsicum annuum L. & & Fruit \\
\hline & Leunca & Solanum nigrumL. & & Fruit \\
\hline & Takokak & Solanum torvum Sw & $\sqrt{ }$ & Fruit \\
\hline & Teronghejo/bodas & Solanum melongena $\mathrm{L}$ & & Fruit \\
\hline & Terongkoneng & Solanum quitoense Lam. & $\sqrt{ }$ & Fruit \\
\hline & Terongungu & Solanum melongena $\mathrm{L}$. & & Fruit \\
\hline & Asparagus & Asparagus cochinchinensis (Lour.) Merr. & $\sqrt{ }$ & Bud, stem \\
\hline & Tomat & Lycopersicum esculentum & & Fruit \\
\hline
\end{tabular}


Table Continued

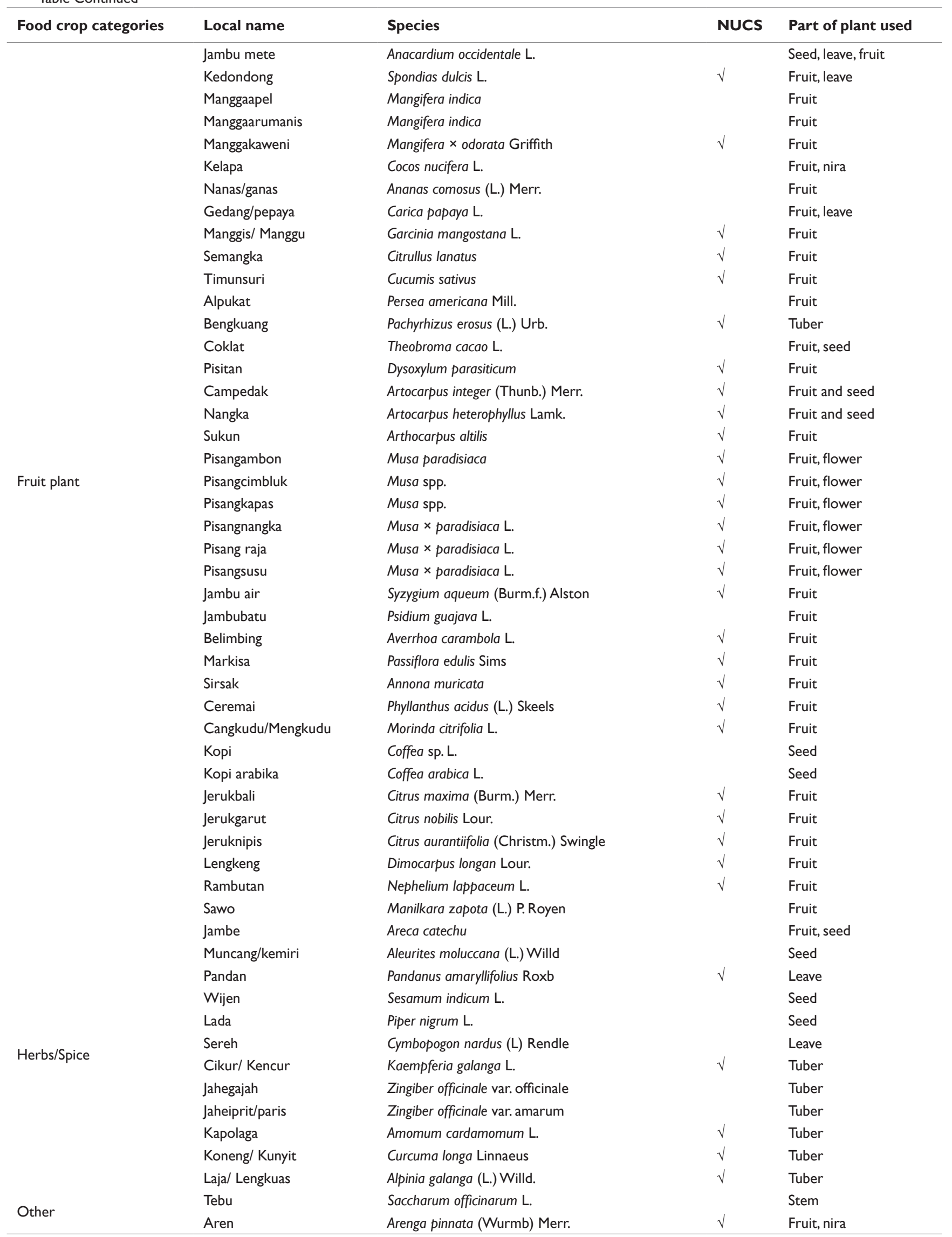




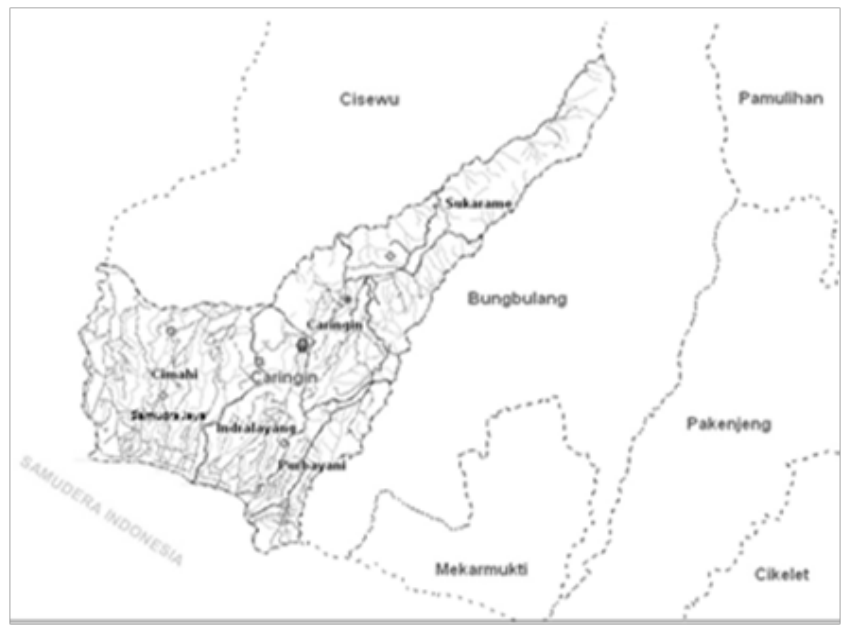

Figure I Location of survey at Rancabuaya, Caringin District, Garut ( $7^{\circ} 3$ I'28', S $\left.107^{\circ} 28^{\prime} 40^{\prime \prime} \mathrm{E}\right)$.

The lack of organized markets, nationally or locally could be another reason of negligence. For example, Gadung (Dioscorea hispida) and Ganyong (Canna discolor) are considered as a source of carbohydrates. Unfortunately, these crops are not popular among the villagers because of its low market value. A consequence of no research support for NUCS has been a lack of crop improvement, ${ }^{1}$ but thanks to the local communities, especially in Rancabuaya who conserved the genetic diversity of those NUCS on their farms.

\section{Nutritional value and utilization of food crop categories Cerealia}

The cereals are essential sources of food, especially carbohydrate, for human. The cereals are the members of family Gramineae. There are five known cereals: rice, wheat, barley, oat, and rye. They contain a high percentage of carbohydrate, along with a substantial amount of proteins, some fats. Vitamins are also present at this food. ${ }^{9}$

Cereals planted by the people at Rancabuaya were mostly corn and rice. These 2 crops are considered as a source of carbohydrate. The villager planted the rice to get an income by selling the grain or to be consumed daily as their staple food. When they had a lot of stock, the grain would be placed at the barn. The villagers also planted corn. However, unlike rice, corn was not grown to substitute rice as staple food. Corn was mostly consumed as "snacks" between meals. Corn was boiled, barbecued or processed into other foods. Its stems and leaves were used as fodder. Based on the research by Bertomeu ${ }^{10}$ in the Philippines, corn can be intercropped with trees at agroforestry systems. The result suggested that intercropping corn gave farmers more profit compared to mono cropping. This is one value that farmers usually looking for the most by applying agroforestry system.

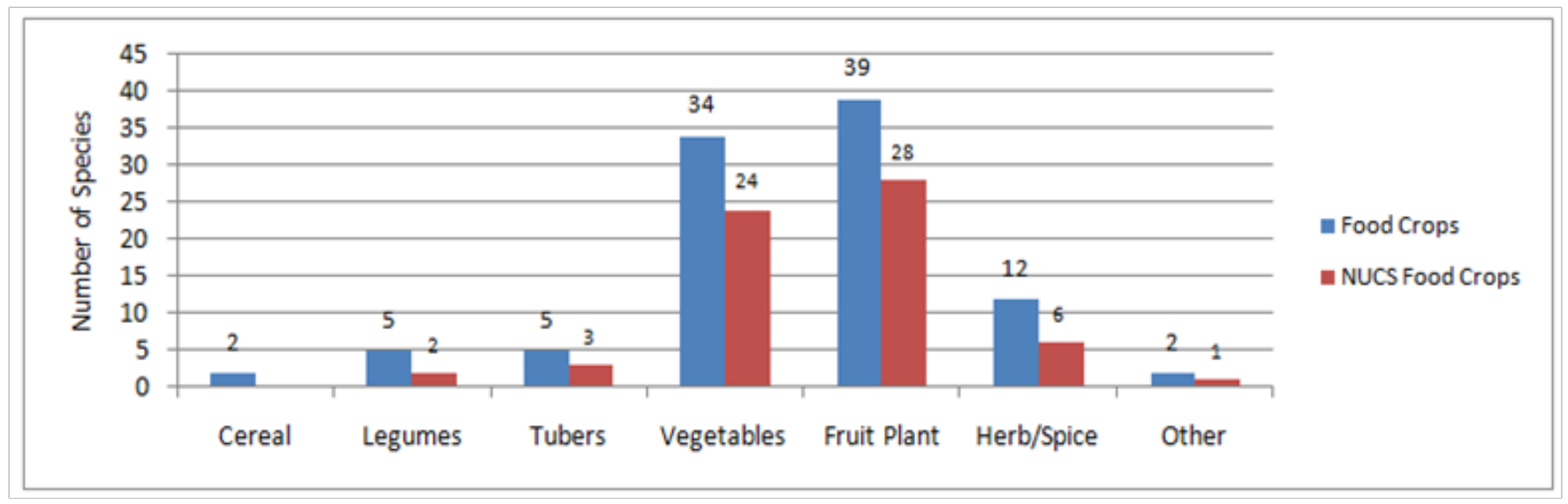

Figure 2 Food Crops Categories in Rancabuaya.

\section{Tubers}

Tubers as food crops have an important value as sources of carbohydrate, alcohol, and all purpose flour. Sweet potato (Ipomoea batatas) is the most popular tubers among others. Even though this crop was not originally from Indonesia, its present has become important for culture and become the main source of carbohydrate for some ethics groups in Indonesia. ${ }^{11}$

As for Rancabuaya, white sweet potato and taro were the two crops that mostly grew by the villagers. Other tuber that was also found in this district was Dioscorea hispida or known by its local name "Gadung". It can be summarized that Dioscorea hispida were found to be good source of protein, lipid, crude fiber, starch, vitamins, and minerals. Beside of that, it contains antinutritional value such as phenolic, tannins, hydrogen cyanide, and oxalate. Although this tuber contains toxin, it can be processed before it is consumed. ${ }^{12,13}$ Its toxicity can be reduced by harvesting when the leaves have started to dry. ${ }^{14}$ Then, the antinutritional value can be eliminated by soaked followed by cooking before consumption. Other than "Gadung", "Ganyong" or generally known as Edible Canna was also found in this area. Carolina and Ilmi (2015) reported that within the starch that have been extracted from tubers of Edible Canna is contained carbohydrate, amylose, amylopectin, protein and fat. Edible Canna starch is a potential source for industrial utilization as a new base of starch. ${ }^{15}$ In Vietnam, its starch is mostly used for preparing transparent starch noodles. ${ }^{16}$ Unfortunately, these two tubers were not popular among the villagers because of the taste and their low economic value. These two crops were usually left alone and there were no treatment, such as fertilizers, given during their growth.

Tubers can be useful at agroecosystem management land. Tubers can live under shade which makes them suitable to be planted together with trees. Sweet potato, for example, has been used in the agroforestry 
system together with poplar in Pakistan. ${ }^{17}$ Panwar and Wani found that there were certain varieties actually produced more yield under poplar trees. This study also suggested that intercropping trees with tubers have more benefit than a monocropping system. Although not being sold due to its taste and low economic value, "Gadung" is quite popular in Nganjuk, Indonesia, also it is mostly sold in the form of processed chips. ${ }^{14}$ With the right process, tubers that found at Rancabuaya can be processed as snacks or any types of meal. These snacks and meal can be sold around tourists' area which certainly will help people in Rancabuaya to raise their income.

\section{Legumes}

The legumes are as important as cereals. They belong to Leguminosae family and full of protein materials than any other vegetable. Legumes also contain fats and carbohydrate. ${ }^{9}$ With such high protein contain, legumes are a substitute for protein source other than meat. Beans are very important for vegetarians. Simpson $\&$ Corner-Ogorzali ${ }^{18}$ stated that in general, legumes are an excellent source of protein. Legumes that found in the Rancabuaya can be used as snack for any tourists that come to visit the village. Legumes can be a good combination with trees and suitable to be used together at agroforestry land management.

Based on research by Osman et al., ${ }^{19}$ at Burkina Faso Africa, cowpea (legumes) can be intercropped together with trees. When cowpea was harvested, people at Burkina Faso had extra income that could support their daily live. Another species of legume, groundnut, was also used in the agroforestry system in North Kordofan State Sudan. ${ }^{20}$ Result showed that planting groundnut together at the system gave a positive impact for villagers' income. These results clearly suggested that planting legumes at the agroforestry system will help people who live around agroforestry area.

\section{Vegetables}

Vegetable is the term applied to edible plants that accumulate its reserve food in fruits, roots, stems, and leaves. Those can be eaten directly as salad or cooked. This crop ranked second to cereals as the source of carbohydrate. Vegetables are known to contain lots of minerals, salts, and vitamins which are very important to this crop ranked second to cereals as the source of carbohydrate. Vegetable are known to contain lots of minerals, salts and vitamins which are very important to be consumed. ${ }^{9}$ Vegetable mostly found in this village were come from Brassicaceae family and Solanaceae family. Compared to other crops found in Rancabuaya, vegetables are easy to be planted together with trees. Vegetable can be used together with trees as a system of agroforestry. Vegetable can be sold by the villagers as their extra source of income. This can strengthen the goal of government agroforestry program where agroforestry should consider the ecology, social and economic of the people.

\section{Fruits}

Ripe fruits are usually eaten raw. Raw fruits can be cooked at eaten as a dessert. Simple fruit is derived from single ovary, while the aggregate fruits are formed from several carpels from the same flower. Ovaries from different flowers can form composite fruit. ${ }^{9}$ Fruit trees are a great choice for agroforestry systems. They produce shade to protect the soil. They also produce fruit that can be consumed or sold. Intercropping fruit trees with vegetable, for example, can give villagers extra income. ${ }^{21}$ Based on the information from the people at Rancabuaya, other than banana, other fruits were not planted with the purpose of getting extra income. These fruits were consumed privately and sometimes used for social events. Banana, however, has been the most planted fruit at this region. Banana variety 'pisangambon', particularly, has been used as raw material for home industry 'sale pisang'. Other fruits also can be processed as snack and can be sold around tourist area. In the agroforestry management land system, fruits trees are a good choice to be used with other crops.

\section{Conclusion}

Rancabuaya has a great diversity of food crops which are potential as human foods. There were 99 species of food crops that can be categorized as cereals, tubers, legumes, fruits, vegetables, herbs/ spices and other. Among those crop lists, there were more than $64 \%$ crop species included to NUCS (73 species). Many of these crops were intercropped with trees which made the agroforestry management in Rancabuaya. Based on many research, these neglected crop species have enormous nutritional value and utility. When developed, they could be an alternative choice to substitute staple crops and raise the income of Rancabuaya villagers by selling them around tourist's area. Unfortunately, insufficiency of promotion from national policy and the lack of development of national or local organized market could be the main reason of negligence of these crop species. It is important to initiate research for these neglected crops development in terms of cultivating practices, processing methods, and marketing promotions..$^{22,23}$

\section{Acknowledgments}

Authors sincerely thank Academic Leadership Grant program from Universitas Padjadjaran for this research.

\section{Conflict of interest}

Authors declare there is no conflict of interest in publishing the article.

\section{References}

1. Padulosi S, Thompson J, Rudebjer J. Fighting poverty, hunger and malnutrition with neglected and underutilized species (NUS): needs, challanges, and the way forward. Biodiversity International, Rome; 2013.

2. Padulosi S, Hoeschle-Zeledon I. Underutilized plant species: What are they? Leisa Magazine, India; 2004.

3. Caringin District. Monograph Caringin District. Caringin, Garut; 2014.

4. Arora RK. Diversity in Underutilized Plant Species-An Asia Pacific Perspective. Biodiversity International, New Delhi; 2014.

5. Soemarwoto O. The Talun-Kebun System, a Modified Shifting Cultivation, in West Java. Environmentalist. 1984;4(7):96-98.

6. Parikesit, Takeuchi K, Abdoellah OS. Kebon Tatangkalan: a Disappearing agroforest in the Upper Citarum Watershed, West Java, Indonesia. Agroforestry Systems. 2004;63(2):171-182.

7. Kosuke M, Mugniesyah SS, Herianto AS, et al. Talun-Huma, Swidden Agriculture, and Rural Economy in West Java, Indonesia. Southeast Asian Studies. 2013;2(2):351-381.

8. Food Crops Research \& Development Center. Laporan akuntabilitas kinerja pusat penelitian dan pengem bangantanama npangantahun 2013. Ministry of Agriculture, Indonesia; 2014.

9. PANDEY BP. Economic Botany. Sixth revised. Chand S and Company Ltd, New Delhi; 2003. 
10. Bertomeu M. Growth and yield of maize and timber trees in small holder agroforestry systems in Claveria, northern Mindanao, Philippines. Agroforest Syst. 2012;84(1):73-87.

11. Waluyo EB. Keanekaragaman Hayati Untuk Pangan. Makalah Kipnas X, Jakarta; 2011.

12. Sibuea SM, Kardhinata EH, Ilyas S. Identifikasi dan inventarisasi jenis tanaman umbi-umbian yang berpotensi sebagai sumber karbohidrat alternatif di kabupaten Serdang Bedagai. Jurnal Online Agroekoteknologi. 2014;2(4):1408-1418.

13. Rubatzky VE, dan Yamaguchi M. Sayuran dunia 1 (prinsip, produksi dan gizi). Penerbit ITB, Bandung; 1998.

14. Trimanto T, Hapsari L. Diversity and utilization of Dioscorea spp. Tuber as Alternative Food Source in Nganjuk Regency, East Java. Agrivita. 2015;37(2):97-107.

15. Imai K. Edible Canna: A Prospective Plant Recource from South America. Japanese Journal of Plant Science. 2008;2(2):46-53.

16. Hung PV, Morita N. Physiochemical properties and enzymatic digestibility of starch from edible canna (Canna edulis) grown in Vietnam. Carbohydrate Polymers. 2005;61(3):314-321.

17. Panwar S, Wani AM. Effect of organic production on growth and productivity of sweet potato (Ipomoea batatas L.) under poplar based agroforestry system. IJAR. 2014;2(12):229-232.
18. Simpson BB, Conner-Ogorzaly M. Economic botany. plants in our world, McGraw-Hill, Inc; 1986.

19. Osman AN, Ræbild A, Christiansen JL, et al. Performance of Cowpea (Vigna anguiculata), and Pearl Millet (Pennisetum glaucum), Intercropped under Parkia biglobosa in an agroforestry system in Burkina Faso. African Journal of Agricultural Research. 2011;6(4):882-891.

20. Fadl KEM, Sheikh SEEL. Effect of Acacia senegal on growth and yield of groundnut, sesame and roselle in an agroforestry system in North Kordofan State, sudan. Agroforest syst: 2010;78(3):243-252.

21. Bali SC, Mondol MA, Akter A, et al. Effect of guava and lemon on the yield of okra under agroforestry system. J Agrofor Environ. 2013;7(1):53-56.

22. Ahmed NO, Raebild A, Christiansen JL, et al. Performance of cowpea (Vigna unguiculata) and pearl millet (Pennisetum glaucum) intercropped under Parkia biglobosa in an agroforestry system in Burkina Faso. African Journal of Agricultural Research. 2011;6(4):882-891.

23. Hasan MR, Akter A, Alam Z, et al. Indian spinach and okra cultivation along with Swietenia hybrida tree as agroforestry practices. J Agrofor Environ. 2012;6(2):119-124. 